\title{
Factors associated with depressive symptoms and cognition in elderly victims of violence
}

\author{
Fatores associados a sintomas depressivos e cognição em idosos(as) vítimas de violência
}

Factores relacionados a los síntomas depresivos y cognición en ancianos(as) víctimas de violencia

'Universidade Federal da Paraíba. João Pessoa, Paraíba, Brazil.

"Universidade Federal de Pernambuco. Recife, Pernambuco, Brazil.

I" UNIFACISA Centro Universitário. Campina Grande, Paraíba, Brazil.

How to cite this article:

Santos RC, Souto RQ, Almeida AM, Araújo GKN, Sousa RCR,

Santos RC. Factors associated with depressive symptoms and cognition in elderly victims of violence.

Rev Bras Enferm. 2020;73(Suppl 3):e20190383. doi: http://dx.doi.org/10.1590/0034-7167-2019-0383

Corresponding author:
Rafaella Queiroga Souto
E-mail: rafaellaqueiroga7@gmail.com

EDITOR IN CHIEF: Antonio José de Almeida Filho ASSOCIATE EDITOR: Italo Silva

\section{ABSTRACT}

Objective: To identify, among elderly people victims of violence, factors associated with depressive symptoms and cognitive function. Method: This was a cross-sectional study carried out with 56 elderly people classified in situation of violence. To do so it was used the Brazil Old Age Shedule (BOAS), the Conflict Tactics Scales Form R, the Geriatric Depression Scale (GDS) and the Mini-mental State examination (MMSE). Results: Depressive symptoms were more predominant in elderly men, over 70 years old, without partner, illiterate, with no job, receiving up to 1 minimum wage and who lived alone; and the cognitive deficit prevailed in women, over 70 years old, without partner, illiterate, who did not work, receiving up to 1 minimum wage and who lived alone. Conclusion: Among the elderly population victim of violence, lack of a partner and cognitive impairment were associated to depressive symptoms; and finding themselves living alone, with no partner and being illiterate were associated to cognitive deficit.

Descriptors: Violence; Depression; Cognition; Elderly; Public health.

\section{RESUMO}

Objetivo: Identificar, entre pessoas idosas vítimas de violência, os fatores associados a sintomas depressivos e função cognitiva. Métodos: Tratou-se de um estudo transversal, realizado com 56 idosos(as) classificados(as) como em situação de violência. Foram utilizados: o Brazil Old Age Shedule, o Conflict Tactics Scales Form R, a Geriatric Depression Scale e o Mini Exame do Estado Mental. Resultados: Os sintomas depressivos foram mais prevalentes nos idosos do sexo masculino, maiores de 70 anos, sem companheiro, analfabetos, sem trabalho, com até 1 salário mínimo e que moravam sozinhos; e o déficit cognitivo predominou nas mulheres, maiores de 70 anos, sem companheiro, analfabetas, que não trabalhavam, com até 1 salário mínimo e que moravam sozinhas. Conclusão: Entre a população idosa vítima de violência, a falta de companheiro e o déficit cognitivo estavam associados aos sintomas depressivos; e encontrarse morando sozinho, sem companheiro e ser analfabeto, ao déficit cognitivo.

Descritores: Violência; Depressão; Cognição; Idoso; Saúde Pública.

\section{RESUMEN}

Objetivo: Identificar, entre los ancianos(as) víctimas de violencia, los factores relacionados a los síntomas depresivos y función cognitiva. Método: Se trató de un estudio transversal, realizado con 56 ancianos(as) clasificados(as) como en situación de violencia. Han sido utilizados: el Brazil Old Age Shedule, el Conflict Tactics Scales Form R, la Geriatric Depression Scale y el Mini Examen del Estado Mental. Resultados: Los síntomas depresivos han sido más predominantes en los ancianos del sexo masculino, mayores de 70 años, sin compañero, analfabetos, sin trabajo, con hasta 1 salario mínimo y que vivían solos; y el déficit cognitivo predominó en las mujeres, mayores de 70 años, sin compañero, analfabetas, que no trabajaban, con hasta 1 salario mínimo y que vivían solas. Conclusión: Entre la población anciana víctima de violencia, la falta de compañero y el déficit cognitivo estaban relacionados a los síntomas depresivos; y encontrarse viviendo solo, sin compañero y ser analfabeto, al déficit cognitivo.

Descriptores: Violencia; Depresión; Cognición; Anciano; Salud Pública.
Submission: 05-14-2019

Approval: 05-14-2020 


\section{INTRODUCTION}

Longevity is a worldwide phenomenon, and the increase in the elderly population has contributed to very significant demographic changes ${ }^{(1)}$. Estimates indicate that Latin America will have, by 2050 , one in four adults over the age of $60^{(2)}$. In Brazil, in recent years (2012 to 2017), the number of elderly people has grown more than $18 \%$, surpassing 30 million individuals in $2017^{(3)}$. This increase was partly due to the reduction in the fertility rate, as well as the increase in life expectancy ${ }^{(2)}$.

The aging process associated with unpreparedness of families and society to deal with those changes revealed an increase in the occurrence of violence against the elderly in developed countries, ranging from $4.6 \%$ and $44.6 \%{ }^{(4)}$. Developing countries such as Colombia, Panama and Brazil register 102,000 cases of violence every year, of which about $37 \%$ are reported against the elderly. From those cases, is observed a frequency of $67.7 \%$ in physical violence and $29.1 \%$ in psychological violence, described in a study carried out in 524 Brazilian municipalities, although those values may be underestimated, given the underreporting ${ }^{(5-7)}$.

According to the World Health Organization $(\mathrm{WHO})^{(8)}$, violence against the elderly can be defined as an intentional phenomenon or not, through an act of aggression or negligence. In relation to typology it may be observed physical, psychological, sexual, financial and/or material violence, as well as abandonment, negligence and self-neglect ${ }^{(9)}$. Changes in physical and mental capacity, which occur during the aging process, associated with disrespect and social inequality, contribute to events of violence against the elderly ${ }^{(10)}$.

This phenomenon triggers physical and psychological illnesses such as: psychosomatic pathologies, progressive attenuation of physical defenses, post-traumatic disorder, sleep disorders, suicide attempts, nutritional deficiencies, depression, and others ${ }^{(11)}$. Among them, depression appears more frequently, causing loss of autonomy and aggravation of preexisting pathological problems ${ }^{(12)}$.

Depression stands out as a serious public health problem, worsened by the fact that it is often underdiagnosed and/or undertreated. It can be characterized as a change in the affective area or mood with significant functional impact in all age groups. Researches indicate a frequency of depressive symptoms in the elderly varying between 19\% and 34\% in different Brazilian regions ${ }^{(13-14)}$.

Depressive symptoms in elderly people are associated with several factors, with emphasis on the female gender, advanced age, lack of companion, low education and income, presence of stressful events, low social support, and violence ${ }^{(15-16)}$. Signs of depression are generally found in elderly people who live somehow in a situation of violence, in addition to presenting other symptoms such as impotence, alienation, guilt, shame, fear, anxiety, denial, post-traumatic disorder and increased risk of death ${ }^{(17)}$.

Mood disorders caused by depression can be a condition to the progress of other phenomena, especially cognitive decline, given that cognitive deterioration is an expressive cause of morbidity and mortality, which can compromise the performance of daily activities, social interaction and quality of life among individuals ${ }^{(18-21)}$. Furthermore, that deterioration has also been associated with structural and functional changes in the brain during the aging process ${ }^{(22)}$.
Cognitive deficit is an impairment in the space-time orientation, the difficulty of attention and memory, consisting in a limiter of social and intellectual activity to the elderly person, causing restriction in their functional capacity ${ }^{(23)}$.

Elderly people with cognitive impairment have a high level of dependency. That excessive need for support, a phenomenon which is a determining element in caregivers' burden, may be a trigger for violence. In a survey conducted in the United Kingdom with family members of demented elderly about $30 \%$ presented violent behavior, registering that the most perpetrated psychological violence has occurred through verbal aggressions ${ }^{(24-25)}$.

\section{OBJECTIVE}

To identify, among elderly people victims of violence, factors associated with depressive symptoms and cognitive function.

\section{METHODS}

\section{Ethical Aspects}

This project is an excerpt from the research "Impact of multidimensional interventions on elderly people registered in Primary Health Care and their caregivers" approved by the Research Ethics Committee (CEP), having met all ethical principles. Furthermore, the results of the investigation were presented to health unit professionals, stressing the importance of measures for controlling and preventing situations of violence, depressive symptoms and cognitive impairment.

\section{Design, place, and period of study}

This is a cross-sectional quantitative research, guided by the Strengthening the Reporting of Observational Studies in Epidemiology (STROBE). It was held in the city of Recife, Pernambuco, Brazil, in the period of 2016 to 2017.

\section{Population and eligibility criteria}

The research was carried out interviewing elderly people linked to the area covered by three teams that are incorporated to the Family Health Unit Sítio Wanderley, in the city of Recife, Pernambuco, Brazil. This unit was selected for this study due to its geographic location close to the Federal University of Pernambuco (UFPE), facilitating the university's social responsibility with the adjacent community.

The study population was composed of 1,209 people referring to the three teams in the aforementioned unit. For the sample calculation of the primary study, the finite population formula was used for epidemiological studies, adopting a confidence coefficient of $92 \%$ and a margin of error of $8 \%$. Based on this calculation, the resulting sample consisted of 159 elderly people.

The sampling was random, systematic type. The number of elderly people was determined by proportionality between the three teams in the health unit. For every five elderly person in the list of each team, one was chosen and invited to participate in the research.

Participated in the research, 60-year-old people or older, registered in the three family health teams in the study area. Those with severe hearing deficits (low hearing or deafness) or 
vision deficits (low visual acuity or blindness) and/or who were in palliative care were excluded. Compliance with those criteria were determined by researchers by means of observation or information from those responsible for the elderly.

For this cut out, 56 elderly people were identified as victims of violence after the application of the Conflict Tactics Scales Form $R$ (CTS- 1 ).

The CTS- 1 is an instrument of Canadian origin and presents 19 questions, which are divided into three groups, based on the types of tactics used to deal with conflicts: argumentation (items $\mathrm{a}-\mathrm{c}$ ), verbal aggression (items $\mathrm{d}-\mathrm{f}$ and $\mathrm{h}-\mathrm{j}$ ) and physical aggression (items k-s). Each item considers three response options: it did not happen, it happened a few times in the last 12 months and it happened several times in the last 12 months $^{(26)}$. As far as the classification of violence against the elderly is concerned, they received the designation "with violence" when they presented at least one positive response in any of the items relative to the scale. This measure was adopted taking into consideration the statements indicating some sign of violence.

\section{Study protocol}

Data collection took place at the elderly residence, after explanations about the objectives of the research, orientation about data confidentiality, willingness to participate and signing in the Informed Consent Form.

For data gathering were used the following instruments:

Brazil Old Age Schedule (BOAS) ${ }^{(27)}$, Geriatric Depression Scale $(\mathrm{GDS})^{(28)}$ and the Mini-mental State examination (MMSE) ${ }^{(29)}$.

The $\mathrm{BOAS}^{(27)}$ it is a multidimensional instrument and was used for sociodemographic characterization of the studied group. From this instrument there were used questions related to age, gender, marital status, level of literacy, job, and income.

The $\mathrm{GDS}^{(28)}$ is a scale for screening depressive symptoms in the elderly population, and in the present study it was used the Short Form version, with 15 items (GDS-15). Participants answered items on a dichotomous response scale, where 1 meant (No) and 2 (Yes). For the analysis, each response indicating a symptom of depression, whether positive or negative, was assigned 1 point. After summation, the range between 0 and 4 was considered normal, from 5 and 10 suggested depression, and between 11 and 15 indicated severe depression. For those data, a variable was recategorized, and individuals with score $\geq 5$ were classified as "depressive symptoms" without indicating the intensity.

The MMSE was applied for elderly cognitive screening. That instrument score ranges from 0 to 30 points, and its cutoff point varies according to the individual's level of education: 13 points for non-literate people, 18 for individuals with low or medium level of education and 26 points for those with high level of education ${ }^{(29)}$.

\section{Analysis of results and statistics}

The collected data were typed in double input by independent typists in statistical software; and the discrepancies were reviewed and corrected by a data collection coordinator.

Afterwards, data were analyzed using descriptive statistics (absolute and relative frequency) and inferential statistics (Pearson's chi-square or Fisher's exact test when the cells had a number equal to or less than 5; and multiple logistic regression). For all analyzes, a significance level of $5 \%(p<0.05)$ was used. For all analyses, it was used the significance level of $5 \%(p<0.05)$.

The nature of the GDS total score distribution was assessed in order to verify the normality of the data using the Komolgorov-Smirnoff test. The variable did not show present a normal distribution.

The criterion for entering factors into the model was $p \leq 0.02$; and, for permanence, those with significance $\leq 0.05$. The modeling strategy used was the Backward.

\section{RESULTS}

Among the individuals studied the prevalence of depressive symptoms was $57.1 \%(n=32)$, and cognitive deficit, $32.1 \%(n=18)$.

Table 1 describes the association between sociodemographic variables, depressive symptoms, and cognitive deficit. It is observed an association of depressive symptoms and self- declared marital status by the elderly ( $p=0.004)$, with predominance among the elderly without a partner (single, widowed, divorced). It was also found a significant statistically association between cognitive deficit and marital status ( $p=0.004)$, literacy $(p=0.005)$ and housing arrangement $(p=0.010)$, prevailing with deficit those elderly people without partners, illiterate and living alone.

Table 1 - Distribution of depressive symptoms and cognitive deficit according to sociodemographic variables among elderly victims of violence, Recife, Pernambuco, Brazil, 2016 2017, N = 56

\begin{tabular}{|c|c|c|c|c|}
\hline \multirow[b]{2}{*}{ Variables } & \multicolumn{2}{|c|}{ Depressive Symptoms } & \multicolumn{2}{|c|}{ Cognitive impairment } \\
\hline & $\begin{array}{c}\text { With } \\
\text { symptoms } \\
\text { n (\%) }\end{array}$ & $\begin{array}{c}\text { With no } \\
\text { symptoms } \\
\text { n (\%) }\end{array}$ & $\begin{array}{c}\text { With } \\
\text { deficit } \\
\text { n (\%) }\end{array}$ & $\begin{array}{l}\text { Without } \\
\text { deficit } \\
\text { n (\%) }\end{array}$ \\
\hline \multicolumn{5}{|l|}{ Gender $(n=56)$} \\
\hline Male & $7(58.3)$ & $5(41.7)$ & $3(25.0)$ & $9(75.0)$ \\
\hline Female & $25(56.8)$ & $19(43.2)$ & $15(34.1)$ & $29(65.9)$ \\
\hline$p$ value & $0.925^{*}$ & & $0.732^{* *}$ & \\
\hline \multicolumn{5}{|l|}{ Age } \\
\hline$\leq 70$ years old & $18(52.9)$ & $16(47.1)$ & $8(23.5)$ & $26(76.5)$ \\
\hline$>70$ years old & $14(63.6)$ & $8(36.4)$ & $10(45.5)$ & $12(54.5)$ \\
\hline$p$ value & $0.430^{*}$ & & $0.086^{*}$ & \\
\hline \multicolumn{5}{|l|}{ Marital status } \\
\hline With partner & $9(36.0)$ & $16(64.0)$ & $3(12.0)$ & $22(88.0)$ \\
\hline With no partner & $23(74.2)$ & $8(25.8)$ & $15(48.4)$ & $16(51.6)$ \\
\hline$p$ value & $0.004^{*}$ & & $0.004^{*}$ & \\
\hline \multicolumn{5}{|l|}{ Literate } \\
\hline Yes & $21(53.8)$ & $18(46.2)$ & $8(20.5)$ & $31(79.5)$ \\
\hline No & $11(64.7)$ & $6(35.3)$ & $10(58.8)$ & $7(41.2)$ \\
\hline$p$ value & $0.450^{*}$ & & $0.005^{*}$ & \\
\hline \multicolumn{5}{|l|}{ Job } \\
\hline Yes & $4(40.0)$ & $6(60.0)$ & $1(10.0)$ & $9(90.0)$ \\
\hline No & $27(60.0)$ & $18(40.0)$ & $17(37.8)$ & $28(62.2)$ \\
\hline$p$ value & $0.304^{* *}$ & & $0.140^{* *}$ & \\
\hline \multicolumn{5}{|l|}{ Income } \\
\hline Up to 1 minimum wage & $23(57.5)$ & $17(42.5)$ & $13(32.5)$ & $27(67.5)$ \\
\hline More than 1 & $9(56.3)$ & $7(43.7)$ & $5(31.3)$ & $11(68.7)$ \\
\hline$p$ value & $0.932^{*}$ & & $0.928^{*}$ & \\
\hline \multicolumn{5}{|l|}{ Housing } \\
\hline Alone & $5(62.5)$ & $3(37.5)$ & $6(75.0)$ & $2(25.0)$ \\
\hline Not alone & $27(56.3)$ & $21(43.7)$ & $12(25.0)$ & $36(75.0)$ \\
\hline$p$ value & $0.741^{*}$ & & $0.010^{* *}$ & \\
\hline
\end{tabular}


Table 2 shows data on the association between cognitive deficit and depressive symptoms. There is a predominance of depressive symptoms among the elderly who presented cognitive deficit $(p=0.006)$.

Table 2 - Association of depressive symptoms and cognitive decline among elderly victims of violence, Recife, Pernambuco, Brazil, 2016-2017

\begin{tabular}{lccc}
\hline Cognitive deficit & \multicolumn{2}{c}{ Depressive Symptoms } & \\
& $\begin{array}{c}\text { With symptoms } \\
\mathbf{n}(\%)\end{array}$ & $\begin{array}{c}\text { No symptoms } \\
\mathbf{n}(\%)\end{array}$ & p value* $^{*}$ \\
\hline With deficit & $15(83.3)$ & $3(16.7)$ & $0.006^{*}$ \\
Without deficit & $17(44.7)$ & $21(55.3)$ & \\
\hline
\end{tabular}

Note: * Pearson's Chi-square test.

The variables such "marital status" and "cognitive deficit" which presented association with the variable "depressive symptoms" were inserted in a bivariate logistic regression model. According to table 3 it was established the association of variable "marital status" with "depressive symptoms". The data about regression allow us to infer that the elderly without a relationship (single, widowed, divorced) presented 5.11 times the chance of developing depressive symptoms.

Table 3 - Variables associated with depressive symptoms by adjusted logistic regression, Recife, Pernambuco, Brazil, 2016-2017

\begin{tabular}{lccc}
\hline Variables & OR & Cl & $\boldsymbol{p}$ value* \\
\hline Marital status & & & \\
In a relationship & 1.00 & - & - \\
$\quad$ No relationship & 5.11 & {$[1.62-16.08]$} & 0.005 \\
\hline Note: $O R=$ Odds Ratio; $C l=$ Confidence interval; ${ }^{*}$ Significance of the test. &
\end{tabular}

\section{DISCUSSION}

The prevalence of depressive symptoms among elderly people in a situation of violence was $57.1 \%$, it was associated with the elderly person who declared themselves without a partner (single, widowed, divorced) and showed a tendency to compromise more those who presented cognitive deficit. As to the cognitive deficit, the prevalence was $32.1 \%$, and it was associated with the condition of the elderly person not having a partner, being illiterate and living alone.

The frequency of depressive symptoms was higher than in a study performed in another state in the Northeast of the country, with elderly people assisted in the family health program and evaluated with the same instrument utilized in the present study ${ }^{(30)}$. This higher frequency of depressive symptoms may be related to the fact that the analysis of depressive symptoms was carried out among victims of violence, although elderly people with depressive symptoms are more vulnerable to episodes of violence ${ }^{(16)}$. The association between depression and abuse among elderly people in India has evidenced that victims of some form of violence were twice as likely to experience depressive symptomatology ${ }^{(31)}$.

It is also noteworthy that the presence of these symptoms generally leads to the perpetuation of violence, since it makes it difficult to break the cycle of aggressions suffered by the elderly people ${ }^{(32)}$. A study conducted with elderly community members who were victims of violence in Portugal - also using the GDS to evaluate the sample - registered that $78.8 \%$ of those people presented depressive symptoms; however, in the data analysis, it was considered for the study the elderly people who scored two or more values regarding depressive symptomatology ${ }^{(33)}$. That difference in the classification cutoff of elderly people with or without symptomatology may have been the factor that generated divergence in the percentage of prevalence in relation to the present study.

Elderly people without a partner are more vulnerable to depressive conditions. Lack of companionship in old age is a phenomenon related to loneliness and associated with depression; moreover, the death of a family member or a particularly important person can also be an event that triggers depressive symptoms ${ }^{(30,34)}$. A study conducted in the countryside of Minas Gerais portrayed this condition as a contribution to cognitive decline, inferring that the presence of company is a factor for greater cognitive stimulation ${ }^{(35)}$. The continuity in family and community relationships contribute to the prevention or delay of cognitive deficit, and the results of the present study confirm that elderly people living without companions had a higher occurrence of cognitive deficit ${ }^{(36)}$. However, in the contemporary world, the family environment has been classified as the main place of perpetration of violence against the elderly, having, most of the time, as aggressors, people inserted in the family context ${ }^{(37-38)}$. It should be noted that, in addition to the company, the family must be prepared to provide social support, considered one of the most relevant aspects for improving the quality of life of the elderly ${ }^{(39)}$.

Although, in this study, the presence of depressive symptoms is more prevalent among elderly males, other studies point out that females are twice as likely to develop depressive conditions, linking this frequency to hormonal effects, stress, among other factors ${ }^{(30,34,40)}$.

The association between depressive symptoms and elderly people without education was evidenced in the study and shows similarity with other researches. The level of education of elderly person can influence in coping with stressful situations, although illiterate elderly present a higher risk for developing depressive symptoms $\mathbf{s}^{(32,41)}$.

A connection was detected between depressive symptoms and cognitive deficit, prevailing among the elderly cognitively compromised, confirming the cognitive deficit as a risk factor for depressive symptomatology ${ }^{(18)}$. The complex interaction of biological and environmental risk factors in triggering depressive symptoms and cognitive deficit in vulnerable individuals is still unknown, although depression among elderly people with cognitive disorders is one of the most common psychiatric syndromes in this group ${ }^{(42)}$. In this current study, elderly people with cognitive deficit had a five times greater chance of presenting depressive symptoms, a reason that may be overestimated due to the situation of violence in this group.

There was an association between cognitive deficit and literacy level, observing that illiterate elderly presented higher cognitive deficit. This context can make them even more vulnerable since this factor added also to the occurrence of depressive symptoms, and it cannot be left out that those elderly researched were victims of violence.

Among the depressive symptoms, cognitive deficit and violence, there is no well-defined cause-and-effect relationship, since the appearance of one of these factors provides a susceptibility for the development of the other and, consequently, aggravates the one already installed. Therefore, it is fundamental that the health professional is trained to track all of those factors, tracing an assistance care planning based on a global, multidimensional and interdisciplinary assessment of the elderly, identifying the 
psychological, social and physical elements, and being able to correlate them based on in the particularities of the elderly people ${ }^{(43)}$.

\section{Limitations of the study}

The following limitations of the study were considered: impossibility of generalization through statistical inference; and shortage of studies in the literature that addressed elderly people in a similar situation to the population of this research.

\section{Contributions to Nursing, Health or Public Policy}

The results of this investigation contribute to the knowledge about the phenomenon of violence against the elderly, improving the assistance of nursing professionals to this population. Furthermore, they favor both the development of future preventive actions against violence against these individuals and the provision of care in an individualized manner taking into account the particularities of each person.

\section{CONCLUSION}

In community elderly people who received the classification "with violence", the presence of factors such as cognitive deficit and finding themselves without a partner present a statistically significant association with the prevalence of depressive symptoms, as well as living alone, being illiterate and not having a partner are associated with cognitive deficit.

\section{REFERENCES}

1. Moreira WC, Damasceno CKCS, Fernandes SKS, Vieira, Campêlo TPT, Campêlo DS, et al. Análise sobre as políticas públicas de enfrentamento a violência contra o idoso. Rev Enferm UFPE. 2016;10(4):1324-32. doi: 10.5205/reuol.8464-74011-1-SM.1004201621

2. Salazar-Barajas ME, Lillo Crespo M, Hernández Cortez PL, Villarreal Reyna MA, Gallegos Cabriales EC, Gómez Meza MV, et al. Factors contributing to active aging in older adults, from the Framework of Roy's Adaptation Model. Investig Educ Enferm. 2018;36(2):e08. doi: 10.17533/udea.iee.v36n2e08

3. Instituto Brasileiro de Geografia e Estatística (IBGE). Ministério do Planejamento O e GD de P. Número de idosos cresce $18 \%$ em 5 anos e ultrapassa 30 milhões em 2017 [Internet]. 2018 [cited 2019 Jan 30]. Available from: https://agenciadenoticias.ibge.gov.br/ agencia-noticias/2012-agencia-de-noticias/noticias/20980-numero-de-idosos-cresce-18-em-5-anos-e-ultrapassa-30-milhoes-em-2017

4. Blay SL, Laks J, Marinho V, Figueira I, Maia D, Coutinho ESF, et al. Prevalence and correlates of elder abuse in São Paulo and Rio de Janeiro. J Am Geriatr Soc. 2017;65(12):2634-8. doi: 10.1111/jgs.15106

5. Castro VC, Rissardo LK, Carreira L. Violence against the Brazilian elderlies: an analysis of hospitalizations. Rev Bras Enferm [Internet]. 2018;71(suppl 2):777-85. doi: 10.1590/0034-7167-2017-0139

6. Paiva MM, Tavares DMS. Violência física e psicológica contra idosos: prevalência e fatores associados. Rev Bras Enferm [Internet]. 2015 Dec;68(6):1035-41. Available from: http://dx.doi.org/10.1590/0034-7167.2015680606i

7. Irigaray TQ, Esteves CS, Pacheco JTB, Grassi-Oliveira R, Argimon IIL. Maus-tratos contra idosos em Porto Alegre, Rio Grande do Sul: um estudo documental. Estud Psicol. 2016;33(3):543-51. doi: 10.1590/1982-02752016000300017

8. United Nations. World Population Ageing 2017. World Popul Ageing: 2017 [Internet]. 2017 [cited 2019 Jan 30];1-124. Available from: http:// www.un.org/en/development/desa/population/publications/pdf/ageing/WPA2017_Report.pdf

9. Faustino AM, Gandolfi L, Moura LBA. Functional capability and violence situations against the elderly. Acta Paul Enferm [Internet]. 2014;27(5):392-8. doi: 10.1590/1982-0194201400066

10. Rodrigues RAP, Monteiro EA, Santos AMR, Pontes MLF, Fhon JRS, Bolina AF, et al. Older adults abuse in three Brazilian cities. Rev Bras Enferm [Internet]. 2017;70(4):783-91. doi: 10.1590/0034-7167-2017-0114

11. Silva CFS, Dias CMSB. Violência contra idosos na família: motivações, sentimentos e necessidades do agressor. Psicol Ciên Prof. 2016;36(3):637-52. doi: 10.1590/1982-3703001462014

12. Frade J, Barbosa P, Cardoso S, Nunes C. Depression in the elderly: symptoms in institutionalised and non-institutionalised individuals. Rev Enferm Ref. 2015;IV Série(No 4):41-9. doi: 10.12707/RIV14030

13. Nery BLS, Cruz KCT, Faustino AM, Santos CTB. Vulnerabilidades, depressão e religiosidade em idosos internados em uma unidade de emergência. Rev Gaúcha Enferm. 2018;39:e20170184. doi: 10.1590/1983-1447.2018.2017-0184

14. Amaral TLM, Amaral CA, Lima NS, Herculano PV, Prado PR, Monteiro GTR. Multimorbidade, depressão e qualidade de vida em idosos atendidos pela Estratégia de Saúde da Família em Senador Guiomard, Acre, Brasil. Cien Saude Colet. 2018;23(9):3077-84. doi: $10.1590 / 1413-81232018239.22532016$

15. Bretanha AF, Facchini LA, Nunes BP, Munhoz TN, Tomasi E, Thumé E. Sintomas depressivos em idosos residentes em áreas de abrangência das Unidades Básicas de Saúde da zona urbana de Bagé, RS. Rev Bras Epidemiol. 2015;18(1):1-12. doi: 10.1590/1980-5497201500010001

16. Apratto Jr PC. A violência doméstica contra idosos nas áreas de abrangência do Programa Saúde da Família de Niterói (RJ, Brasil). Cien Saude Colet. 2010;15(6):2983-95. doi: 10.1590/S1413-81232010000600037

17. Garbin CAS, Joaquim RC, Rovida TAS, Garbin AJI. Elderly victims of abuse: a five year document analysis. Rev Bras Geriatr e Gerontol. 2016;19(1):87-94. doi: 10.1590/1809-9823.2016.15037 
18. Faber LM, Scheicher ME, Soares E. Depressão, declínio cognitivo e polimedicação em idosos institucionalizados. Rev Kairós Gerontol. 2017;20(2):195. doi: 10.23925/2176-901X.2017v20i2p195-210

19. Schikowski T, Vossoughi M, Vierkötter A, Schulte T, Teichert T, Sugiri D, et al. Association of air pollution with cognitive functions and its modification by APOE gene variants in elderly women. Environ Res. 2015 Oct;142:10-6. doi: 10.1016/j.envres.2015.06.009

20. Sposito G, Neri AL, Yassuda MS. Advanced Activities of Daily Living (AADLs) and cognitive performance in community-dwelling elderly persons: Data from the FIBRA Study - UNICAMP. Rev Bras Geriatr e Gerontol. 2016;19(1):7-20. doi: 10.1590/1809-9823.2016.15044

21. Votruba KL, Persad C, Giordani B. Cognitive Deficits in Healthy Elderly Population With "Normal" Scores on the Mini-Mental State Examination. J Geriatr Psychiatry Neurol. 2016;29(3):126-32. doi: 10.1177/0891988716629858

22. Sánchez-Moguel SM, Alatorre-Cruz GC, Silva-Pereyra J, González-Salinas S, Sanchez-Lopez J, Otero-Ojeda GA, et al. Two different populations within the healthy elderly: lack of conflict detection in those at risk of cognitive decline. Front Hum Neurosci. 2018;11. doi: 10.3389/fnhum.2017.00658

23. Nunes JD, Saes MO, Nunes BP, Siqueira FCV, Soares DC, Fassa MEG, et al. Indicadores de incapacidade funcional e fatores associados em idosos: estudo de base populacional em Bagé, Rio Grande do Sul. Epidemiol Serv Saúde [Internet]. 2017;26(2):295-304. doi: 10.5123/ S1679-49742017000200007

24. Lino VTS, Rodrigues NCP, Camacho LAB, O'Dwyer G, Lima IS, Andrade MKN, et al. Prevalência de sobrecarga e respectivos fatores associados em cuidadores de idosos dependentes, em uma região pobre do Rio de Janeiro, Brasil. Cad Saude Publica. 2016;32(6). doi: 10.1590/0102-311X00060115

25. Lino VTS, Rodrigues NCP, Lima IS, Athie S, Souza ER. Prevalência e fatores associados ao abuso de cuidadores contra idosos dependentes: a face oculta da violência familiar. Cien Saude Colet. 2019 Jan;24(1):87-96. doi: 10.1590/1413-81232018241.34872016

26. Hasselmann MH, Reichenheim ME. Adaptação transcultural da versão em português da Conflict Tactics Scales Form R (CTS-1), usada para aferir violência no casal: equivalências semântica e de mensuração. Cad Saúde Pública. 2003;19(4):1083-93. doi: 10.1590/S0102-311X2003000400030

27. Veras RP, Souza CA, Cardoso RF, Milioli R, Silva SD. Pesquisando populações idosas--a importância do instrumento e o treinamento de equipe: uma contribuição metodológica. Rev Saude Publica. 1988;22(6):513-8. doi: 10.1590/S0034-89101988000600008

28. Almeida OP, Almeida SA. Confiabilidade da versão brasileira da Escala de Depressão em Geriatria (GDS) versão reduzida. Arq Neuropsiquiatr [Internet]. 1999;57(2B):421-6. doi: 10.1590/S0004-282X1999000300013

29. Melo DM, Barbosa AJG. O uso do Mini-Exame do Estado Mental em pesquisas com idosos no Brasil: uma revisão sistemática. Cien Saude Colet. 2015;20(12):3865-76. doi: 10.1590/1413-812320152012.06032015

30. Magalhães JM, Carvalho AMB, Carvalho SM, Alencar DC, Moreira WC, Parente ACM. Depression among the elderly in the family health strategy: a contribution to primary care. Rev Min Enferm. 2016;20. doi: 10.5935/1415-2762.20160016

31. Mawar S, Koul P, Das S, Gupta S. Association of physical problems and depression with elder abuse in an urban community of North India. Indian J Community Med. 2018;43(3):165-9. doi: 10.4103/ijcm.IJCM_249_17

32. Gil AP, Santos AJ, Nicolau R, Santos C. Fatores de risco de violência contra as pessoas idosas: consensos e controvérsias em estudos de prevalência. Configurações . 2015;(16):75-95. doi: 10.4000/configuracoes.2852

33. Gil AP, Santos AJ, Kislaya I, Santos C, Mascoli L, Ferreira Al, et al. Estudo sobre pessoas idosas vítimas de violência em Portugal: sociografia da ocorrência. Cad Saude Publica. 2015;31(6):1234-46. doi: 10.1590/0102-311X00084614

34. Gullich I, Duro SMS, Cesar JA. Depressão entre idosos: um estudo de base populacional no Sul do Brasil. Rev Bras Epidemiol. 2016;19(4):691701. doi: 10.1590/1980-5497201600040001

35. Tavares DMS, Ferreira PCS, Dias FA, Souza LDM, Gonçalves JRL, Rodrigues LR. Aspectos sociodemográficos e desempenho cognitivo de idosos residentes na zona rural. Av Enferm. 2017;35(3). doi: 10.15446/av.enferm.v35n3.61789

36. Gurian F, Beatriz M, Oliveira D, Celia R, Roberto M, Rodrigues Jr AL, et al. Screening cognitive function of non-institutionalized elderly. Rev Bras Geriatr Gerontol. 2012;15(2):275-83. doi: 10.1590/S1809-98232012000200010

37. Guimarães APS, Górios C, Rodrigues CL, Armond JE. Notification of intrafamily violence against elderly women in the city of São Paulo. Rev Bras Geriatr e Gerontol. 2018;21(1):88-94. doi: 10.1590/1981-22562018021.160213

38. Rodrigues $\mathrm{CL}$, Armond JE, Gorios C. Physical and sexual aggression against elderly persons reported in the city of São Paulo. Rev Bras Geriatr e Gerontol. 2015;18(4):755-60. doi: 10.1590/1809-9823.2015.14177

39. Guedes MBOG, Lima KC, Caldas CP, Veras RP. Apoio social e o cuidado integral à saúde do idoso. Physis Rev Saúde Coletiva. 2017;27(4):1185204. doi: 10.1590/s0103-73312017000400017

40. Lopes JM, Fernandes SGG, Dantas FG, Medeiros JLA. Associação da depressão com as características sociodemográficas, qualidade do sono e hábitos de vida em idosos do Nordeste brasileiro: estudo seccional de base populacional. Rev Bras Geriatr e Gerontol. 2015;18(3):521-31. doi: 10.1590/1809-9823.2015.14081

41. Ramos GCF, Carneiro JA, Barbosa ATF, Mendonça JMG, Caldeira AP. Prevalência de sintomas depressivos e fatores associados em idosos no norte de Minas Gerais: um estudo de base populacional. J Bras Psiquiatr. 2015;64(2):122-31. doi: 10.1590/0047-2085000000067

42. Wang S, Blazer DG. Depression and Cognition in the Elderly. Annu Rev Clin Psychol [Internet]. 2015 Mar 28;11(1):331-60. doi: 10.1146/ annurev-clinpsy-032814-112828

43. Marques GCS, Rodrigues JS, Rodrigues SG, Souza MR, Barros PS, Borges CJ. Profissional Enfermeiro : Competências e habilidades para a avaliação multidimensional da pessoa idosa. Rev Kairós-Gerontol. 2018;21(2):307-26. doi: 10.23925/2176-901X.2018v21i2p307-326 